\title{
Activation of integrin and ceramide signalling pathways can inhibit the mitogenic effect of insulin-like growth factor I (IGF-I) in human breast cancer cell lines
}

\author{
CM Perks, ZP Gill, PV Newcomb and JMP Holly \\ Division of Surgery. Department of Hospital Medicine. Level 7. Bristol Royal Infirmary, Bristol BS2 8HW, UK
}

Summary Cell counting, cell cycle analysis and Western immunoblotting were used to examine the effects of non-apoptotic doses of a ceramide analogue, C2. and a synthetic arginine-glycine-aspartic acid (RGD)-containing peptide, RGD, in MCF-7 and T47D cells to determine whether activation of these signalling pathways could alter the mitogenic potential of insulin-like growth factor I (IGF-I). IGF-I alone increased total cell number in both cell lines, associated with a rise in the percentage of cells in the S-phase of the cell cycle and a co-incident increase in cyclin A production. Treatments alone had no effects on cell number or cyclin A production relative to controls. C2 inhibited IGF-1. induced mitogenesis in both lines, whereas RGD was only effective in the T47D line. Despite inhibition of cell proliferation, IGF-I stimulation of cells in S-phase and of cyclin A levels were unaffected; however, an IGF-t-induced increase in cyclin B1 levels was inhibited by $30 \%$. Lowdose induction of integrin and ceramide signalling pathways causes cells to be blocked in S-phase, thereby inhibiting the normal cycle of events associated with the IGF-I-induced mitotic signal. Activating these pathways may not only restrict fumour growth by induction of apoptosis but they may also directly inhibit IGF-I-induced cell proliferation.

Keywords: integrin and ceramide signalling; insulin-like growth factor I-induced mitogenesis; breast cancer

Insulin-like growth factors (ICiFs) stimulate the growth of many different cell types including human breatst cantecr cells (De Leon

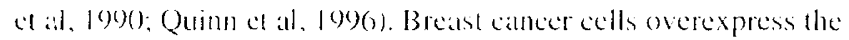
rype I IC if receptor (Papa ct al. I993), and plasma IGF-I concentrations are higher in primary breast canner patients (Peyral et al, 199.3). Therefore, KGF-I could be important for maintaining tumour growth in the breast.

The growth of normal adherent cell types in vitro requires not only grow th factors but also attachment to the extracellular matrix (lic.i) (Ingher, 1990). Cell adhesion to the ECM is mediated by integrin receptors. These bind to matrix proteins outside the cell and issociate with cytosketetal proteins within the cell. Several matrix proteins contain the three-amino-acid sequence, arginine-glycine-aspartic acid (RGD), which is specifically recognized by particular integrin receptors (Ruoslathti et al. 1987). Specifically, integrin-dependent signals have been shown to modulate the control of growth (Giancotti and Ruoslahti. 1990) and cell survival (Frisch and Francis. 1994). Maintenance of integrin linkiges is essential for cell adhesion. It has been demonstrated previously that disruption of these attachments. via addition of antibodies or peptides. can induce cells to detach from the substratum (Knudson et al. 1981: Hayman et al. 1985) with a resultant induction of programmed cell death. Cells which become transformed or malignant must. therefore. have acquired the ability to undergo anchorage-independent growth (Freedman and Shin. 1974: Tucker et al. 1981).

Received 10 February 1998

Revised 11 May 1998

Accepted 23 July 1998

Correspondence to: CM Perks
The plasma membrane is also the site of sphingomyelin hydrolysis, which is now recoentized as an important pathway of signal transduction. Ceramide is one prodect of sphingonyelin hydrolysis and has been implicated as an important mediator of eell death (Obeid el al. 1993). Tumour growth can be restricted by cylokines. chemotherapy and ratlotherapy. which induce programmed cell death via ceramide-mediated cytoplasmic signalling.

The eell cycle is composed of four phases. entry into the cycle (G), which is dependent on the presence of growth factors. the phase after DNA replication ( $\left.\mathrm{C}_{2}^{2}\right)$, and the mitotic phase (S) which culminates in cell division (M). On closer examination. it is evident that the cell cycte is a very complex precess and relies on a number of different components to ensure an ordered completion of cell division (Grana and Reddy, 1995). One such group of components which plays an essential role is the cyclins. which all undergo periodic synthesis and degradation throughout the cell cycle.

In previous studies (Gill et al. 1997a, 1997b: Perks et al. 1997) in which we have used ceramide and integrin detachment for inducing apoptosis to investigate IGF survival effects. we had observed that at doses below those required to induce programmed cell death there was marked attenuation of IGF-induced mitogenesis. In this study, we have investigated further how activation of ceramide and integrin signalling pathways may affect IGF-Iinduced cell proliferation in human breast cancer cells.

\section{MATERIALS AND METHODS}

Recombinant human IGF-I was purchased from GroPep. Adelaide. Australia. The ceramide analogue C2 (D-erythro-sphingosine. $N$-acetyl-) and its negative control (D-enthro-sphingosine. dihydro-. V-Acetyl-) were bought from Calbiochem. and the 
synthetic RGD-containing peptide (Gly-Arg-Gly-Asp-Thr-Pro) logether with its negative control peptide RGE (Arg-GlyGlu-Ser were bought from Sigma. All other reagents were purchased from Sigma or Merck unless otherwise stated.

\section{Cell culture}

Human breast cancer cell lines T47D and MCF-7 were purchased from ECACC. Porton Down. Wiltshire. LK. and grown in a humidified $5 \%$ carbon dioxide atmosphere at $37^{\circ} \mathrm{C}$. The cells were cultured in Dulhecio's modified Eagle medium (DMEM) with glutamax-1 and minimum essential medium Eagle respectively. Both medial were supplemented with $10 \%$ fetal calf serum (FCS: Adranced Prolein Products). penicillin (5000) $\mathrm{JU} \mathrm{m}^{-1}$. streptomycin (5 me $m l^{1}$ ) and L-glutamine (2 m.s. $)$.

\section{MTT assay}

MTT reagent (3-14.5-dimethylthiarol-2-yl]-2.5-diphenyltetrazolium bromide: Thiazolyl blec) is converted into a coloured waller insoluble formazan salt by the metabolic activity of viable cells and can be used as a crude measure of cell viability. Cells were seded at $5 \times 10+\mathrm{m} / 1(150 \mu 1$ growth medium $)$ in 96-well plates and were allowed to grow tor 24 h. Growh medium was replaced with plenol-red-fiee, sertm-free Hepes-buffered DMEM and Hams nutrien mix 1-12 supplemented with sodium hicatrbenate $(0.12 \%$ ) bovine serum alloumin (0.2 mg ml-1) and transferrin (0.0) me ml ') (SFM: $100 \mu 1) 2+$ h before dosing. MTr reagent (7.5 me ml r) in phosphate-bulfered saline (PBSS) was alded to the cells ( 10 pl per well) and the cultures were incubalted for $30 \mathrm{~min}$ at $37^{\circ}$ ( . The reation was stopped by the addition of

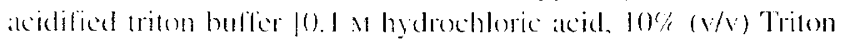
$X-100): 50 \mu 1$ per well] and the cetrazolium erystals were dissolved by mixing on a Titerek plate shaker for 20 min at room temperatture. The samples were mealsured on a Biorad 4.50 plate reader al kest wavelenglly of $595 \mathrm{~nm}$ and a reference wavelength of $6.50 \mathrm{~nm}$. Results represent the means \pm s.e.m. of five wells from one experiment. Which is representative of experiments repeated at leatst thee times: results are expressed als a perentige optical density of S1: 11 controls.

\section{Cell counting}

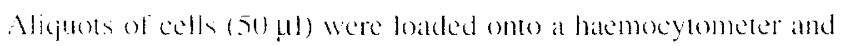
like total cedl number wats determined.

\section{Flow cytometry}

Cells were grown $1065 \%$ confluency in six-well dishes (Nunclon) and then washed with phosphate-bulfered saline $(\mathrm{PBS}: \times 2)$. The grow th medium was replaced with SEN for $24 \mathrm{~h}$. Cells were then trated with ICF-I (100 ng m! 11 ). a sythetic RGD-containing peptide $(10$ or $15 \mu \mathrm{m}$ m 1 ; or ceramide $(1 \mu \mathrm{x})$ and coincubations of IGF-1 with either RGD or C2. and incubated at $37^{\circ} \mathrm{C}$ for $48 \mathrm{~h}$. All cells were collected. washed in PBS and fixed by the addition of Foc ethamol ( $1 \mathrm{ml}$ : 36 min). Cells were then pelleted 6500 rpm.: 5 mint and washed three tumes with PBS 16500 r.p.m.: 5 mint. The supernatant wis removed and the cells were resuspended in reaction buffer (propidium iodide. $0.05 \mathrm{mg} \mathrm{ml}:$ sodium citrate. 0.1\%: RNAse A. $0.02 \mathrm{mg}$ mt: $: \mathrm{P}-40.0 .3 \%: \mathrm{pH} 8.3$ ) vortexed and incubated at $\mathrm{f}^{\circ} \mathrm{C}$ for $30 \mathrm{~min}$. All cells were then measured on a Facscalibur flow cytoneter (Beckton Dickinson) by an argon laser at $488 \mathrm{~nm}$ for excitation. and analysed using Cell Quest (Beckton Dickinson) and Multicycle (Phoenix).

\section{Western immunoblotting}

Cells were grown to $65 \%$ confluency in T25 flasks (Nunclon) and then washed wice with PBS. The growth medium was replaced with SFM for $24 \mathrm{~h}$. treated as above for $48 \mathrm{~h}$ and then lysed on ice for $10 \mathrm{~min}$ ( $1 \mathrm{ml}: 10 \mathrm{~m} . \mathrm{s}$ tris-HCl. $5 \mathrm{~m} . \mathrm{1}$ EDTA. 50 m.1 sodium chloride. $30 \mathrm{~m} \times$ sodium pyrophosphate. $50 \mathrm{m.1}$ sodium fluoride, 100 ux sodium orthoranadate. 1\% Triton. $1 \mathrm{~ms}$ phenylmethylsulphonyl fluoride: $\mathrm{pH}$ 7.6). A protein assay was then performed on the lysates for nomalization of protein levels between samples. The proteins were separated by $12 \%$ sodium dodecyl sulphate (SDS) polyacrylamide gel electrophoresis and then transferred onto a nylon membrane. which was probed with either anti-human cyclin $\mathrm{Bl}$ or anti-human cyclin A (both at $1.5 \mu \mathrm{g} \mathrm{ml}:$ Pharmingen) overnight. After the removal of excess unbound antibody, antimouse $\lg _{\mathrm{f}}$ and $\mathrm{lg} E$ antibodies conjugated to peroxidalse $(1: 3000)$ were added for $1 \mathrm{~h}$. Binding of the peroxidase was visuatized by enhanced chemiluminescence according (1) the manuficturers instructions (Amersham International). Optical density measurements were determined using a scanning densitometer (Biorad) and analysed using Molecular Analyst software (Biorad).

\section{Statistical analysis}

The data were analysed using the Microsolt Exeel t.0a sofiware package. Significant effects were determined using Students $t$-test. A statistically signilicant difference was considered to be presient all $P<0.05$.

\section{RESULTS}

We investigated the metibetic alctivity of $\mathrm{T}+7 \mathrm{I}$ ) and MCF-7 human breast cancer cell lines in response to R(iD) and C2. We also used the comesponding negative controls for the RGD and C2, as outlined in the Matcrials and Methods section. to establish that the effects of these treatments were specific. The MTT assay was used initially as a crude maasurement of cell viability, and this showed that the addition of R(BD) wo the T47D) (ligure $1 A$ ) and MCF-7 cells (datil not shown) and $\mathrm{C} 2$ to the MCF-7s (Figure 1B) and T+7Ds (datia not shown) induced at dose-dependent decrease in metabolic atelivity. The control treatments had no ellects on the cells.

Flow cytometry was then used (1) establish whether this decrease in metabolic activity was due to the induction of programmed cell death or apoptosis and the specific doses at which this occurred. Apoptotic cells hate a lower DNA content than normal cells and appear as a pre-Cil peati on a DNA cell cycle histogram. These experiments demonstrated that there was no apoptosis occurring at RGD doses up 10 and including $10 \mu \mathrm{g} \mathrm{m} \mathrm{m}^{-1}$ in the T47D cells (Figure IC) and MCF- 7 cells (data not shown) and at $C 2$ doses of $2 \mu \mathrm{M}$ and below in the MCF-7 (Figure (D) and T47D cells (data not shown). However. We established that the large reductions in metabolic activity observed in the UTT assays seen at doses of. for example. $100 \mu \mathrm{g}-\mathrm{ml}^{-} \mathrm{RCD}$ in the $\mathrm{T}+7 \mathrm{D}$ (Figure $1 C$ ) and MCF- 7 cells (data not shown and at $C 2$ doses of 10 ux in the MCF-7 (Figure 1D) and T+7D cells (data not shown) were associated with the induction of programmed cell death. 
A

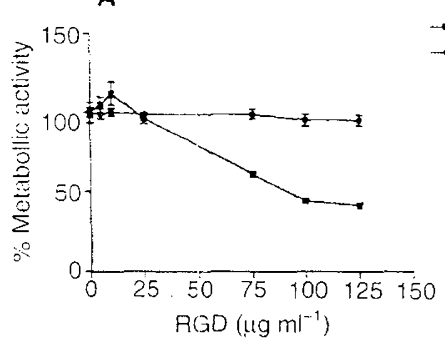

C

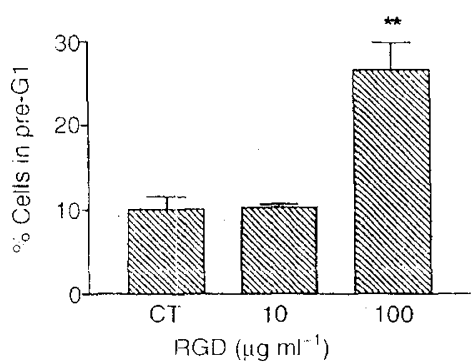

B

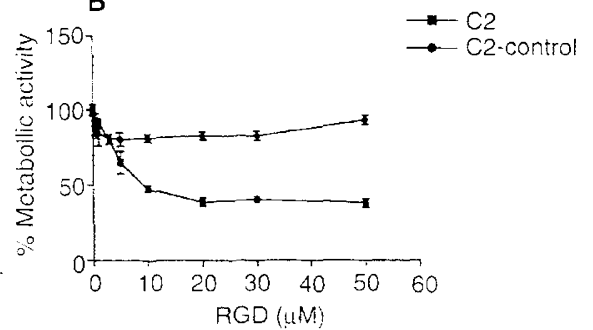

D

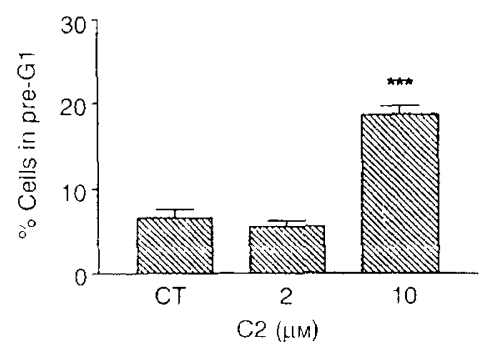

Figure 1 (A) Effects of RGD and RGE (control) (0-125 $\mu \mathrm{g} \mathrm{ml}^{-1}$; in which $P<0.05-0.001$ at doses of RGD $>25 \mathrm{up}$ to $125 \mu \mathrm{g} \mathrm{ml}$ ') and (B) C2 and dihydro-C2 (control) $(0-50 \mu \mathrm{M}$; in which $P<0.05-0.001$ at doses of $C 2$ of $5-50 \mu \mathrm{m})$ on the metabolic activity of T47D and MCF-7 cell lines, respectively, after treatment for $48 \mathrm{~h}$. MTT activity was assayed as described in Materials and methods. The results represent the means \pm s.e.m. of five wells from one experiment, which is representative of experiments repeated at least three times. ( $C$ and $\mathbf{D}$ ) Measurement of apoptosis by flow cytometry represents the percentage of cells in the pre-G1 peak of each treated sample in the T47D $\left(0,10\right.$ and $\left.100 \mu \mathrm{g} \mathrm{ml}{ }^{1}\right)$ and the MCF-7 $(0,2$ and $10 \mu \mathrm{M})$ cell lines, respectively, after $48 \mathrm{~h}$ treatment. Results represent \pm s.e.m. for each dose performed in triplicate simultaneously, and are representative of experiments repeated at least three times $(" * P<0.01$, $\cdots P<0.001)$

Haring established nonapoptotic doses of these tratments, their cllects on the mitogenic potential of IGF-I was then examined. The totat eell counts (I"igure $2 \mathrm{~A}$ and B) revealed that IGI-I at $1(0) n g \mathrm{~m}^{\prime}$ caused a significant $(P<0.05, P<0.001)$ increase in lotal cell number relative to controls in both the T47D) and MCF-7 (cll liaks respectively. Addition of RGD (10) $\mu \mathrm{g} \mathrm{ml}$ ') alone to 1771) (Figure 2A) or MCF-7 (data not shown) cell lines caused no ignilicant differences in cell number in comparison to controls. The addition of RGD ( $10 \mu \mathrm{g}$ ml ') in combination with $100 \mathrm{ng} \mathrm{ml}$ ' Irif-I to the T47D cell line caused a significant $(P<0.0)$ I) decrease in cell number compared with IGF-I alone (Figure 2A), but this treatnent had no effect on IGF-l-induced cell proliferation in the MCF-7 cell line (data not shown). Ceramide analogue C2 (1 $\mu \mathrm{M})$ alone had no effect on cell number relative to control cells in the MCF-7 (Figure 2B) or T47D (data not shown) cell lines compared with the controls. However, in combination with $100 \mathrm{ng} \mathrm{ml}^{-1}$ IGFI. $C 2(1 \mu \mathrm{M})$ caused a significant $(P<0.01)$ decrease in total cell number compared with IGF-I alone in both the MCF-7 (Figure 2B) and T47D (data not shown) cell lines.

Having established that the RGD treatment was only effective in inhibiting IGF-I-induced mitogenesis in the TH7Ds, we proceeded 10 perform all following experiments using RGD specifically in the $T+7 D$ cells and $C 2$ only in the MCF-7 cells.

The MTT assay further indicated that IGF-I alone caused an approximate 1.6-fold and 2-fold increase in metabolic activity in the T47D and MCF-7 cells respectively. The IGF-I-induced increase in metabolic activity was reduced by approximately $56 \%$ with a nonapoptotic dose of $10 \mu \mathrm{g} \mathrm{m} \mathrm{l}^{-1} \mathrm{RGD}$ in the T+7D cells. and by approximately $35 \%$ with 1 M. $\mathrm{C} 2$ in the MCF-7 cells (Figure $3 \mathrm{~A}$ and $\mathrm{B}$ ).
The ecll cycke was then studied to see whether (2 or RGD were inhibiting the entry of cells into the S-phase of the cycle. Results demonstrated in the T47D cells (Figure 4A) that IGF-I alone, as expected. caused a significant $(P<0.001)$ increase in celts in the $S$-phase of the cycle. IGF-I in combination with RGD still caused a significant $(P<0.001)$ increase in cells in the S-phase. Similarly. in the MCF-7 cells (Figure 4B), IGF-I alone and IGF-I in addition to $\mathrm{C} 2$ both produced significant $(P<0 .(0))$ increases in $S$-phase.

Figure 5 summarizes the different dose-dependent activities of ceramide and illustrates how IGF-I acts under these conditions. C2 at $0-2 \mu \mathrm{M}$ has no effect on metabolic activity. but can completely negate the proliferative activity of IGF-I at these doses. C2 at 2$15 \mu . M$ induces apoptosis in these cells, which can be prevented by the addition of IGF-I at this dose. Furthermore, necrosis occurs at $\mathrm{C} 2$ doses of $>15 \mu \mathrm{M}$ and the cells cannot be rescued from this form of cell death by IGF-I. These data have also been confirmed by cell cycle analysis with flow cytometry (data not shown).

To confirm the cell counting which showed that $\mathrm{C} 2$ was inhibiting the mitogenic effect of IGF-I in the MCF-7s, cyclins representative of particular stages of the cell cycle were examined using Westem immunoblotting. Cyclins are essential for cell cycle control and they undergo periodic synthesis and degradation. Cyclin A is synthesized during the S-phase and our data (Figure 6) demonstrated that IGF-1 in the MCF-7 cells caused a 2.9-fold increase in cyclin A production compared with control cells. This increase was maintained on co-incubation with $\mathrm{C}_{2}$. Cyclin Bl is first synthesized during late $S$-phase. and is maximally expressed during the transition from G2 to M-phase. Our results showed that cyclin $\mathrm{Bl}$ production was increased 2.5-fold compared with control levels by IGF-I alone. but. on co-incubation with C?. 

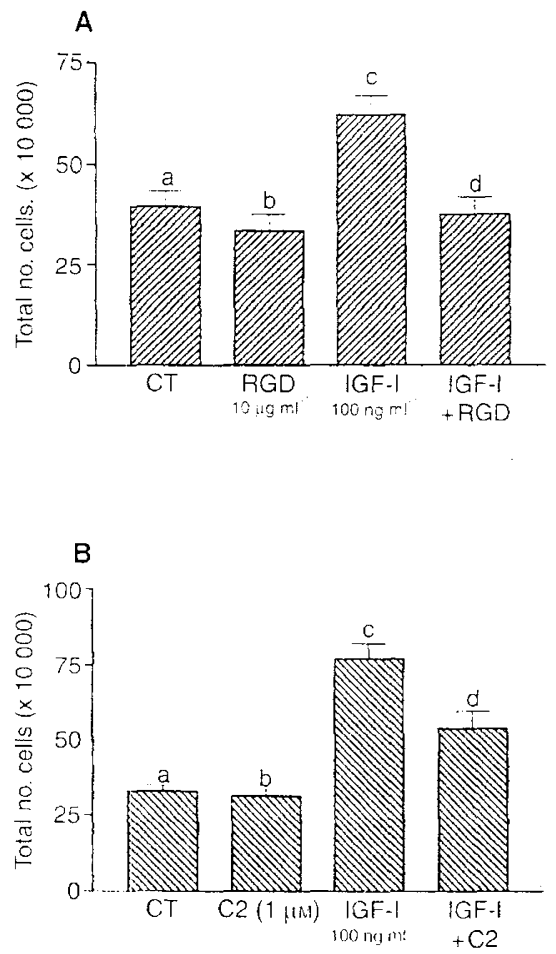

Figure 2 Measurement of total cell number in T47D and MCF-7 human breast cancer cell lines. (A) T47D cells treated with RGD $\left(10 \mu \mathrm{g} \mathrm{ml}^{-1}\right)$, IGF-I $\left(100 \mathrm{ng} \mathrm{ml}^{1}\right)$ or RGD and IGF-l for $48 \mathrm{~h}$ in which $\mathrm{c}>\mathrm{a}(P<0.05)$ and $\mathrm{d}<\mathrm{c}$ $(P<0.01)$. Results are the means \pm s.e.m. of experiments repeated at least three times. (B) MCF-7 cells treated with $\mathrm{C} 2(1 \mu \mathrm{M})$. IGF-I (100 $\left.\mathrm{ng} \mathrm{ml}^{\prime}\right)$ or $\mathrm{C} 2$ and IGF-I for $48 \mathrm{~h}$ in which $\mathrm{c}>\mathrm{a}(P<0.001)$ and $\mathrm{d}<\mathrm{c}(P<0.01)$. Results are the means is.e.m. of experiments performed at least three times

ICir-I-induced cyclin BI production was decreased by approximatcly $30 \%$. Preliminary data have shown that comparable changes in cyctin BI production occured in the T+7D cells alter treillment with R(B) and ICBF-I (datat not shown).

\section{DISCUSSION}

Neoplastic growth catl result liom cither a disturbance in the reget lation of eell probliteation or in the regalation of cell apoptesis. Since this became apparent, there has been considerable investigattion of the laxcors that regulate apoptosis and their role in controtling tumour growth. Although control of cell proliteration and apoptosis are clearly two distinct processess in this study we hatse demonstrated cross-talk between their regulation. Two importatnt mechanisms for controlling apoptosis that have heen identified atre detathment of integrin receptors from the extracellular matrix and cramide signalling in response to chemotherapy. radiotheraps and cytokines. We have shown that signalling involved in both of these processes can interfere with the response to an important proliferatic growth signat. and that this occurs at levels of signalling below that required to indece apoptosis. This indiattes that detachment of integrin receptors and ceramide signalling may cortict tumour growth by atfecting both cell proliferation and cell apoptesis

The atcis ation of the IGF-I receptor by its ligands IGF-I. IGF-II and insulin play a critical role in growth and development isara and Hall. 1990): Basergat and Rubin. 19931. In tumour growth. an obvious imbalance occurs with cell probiferation far exceding
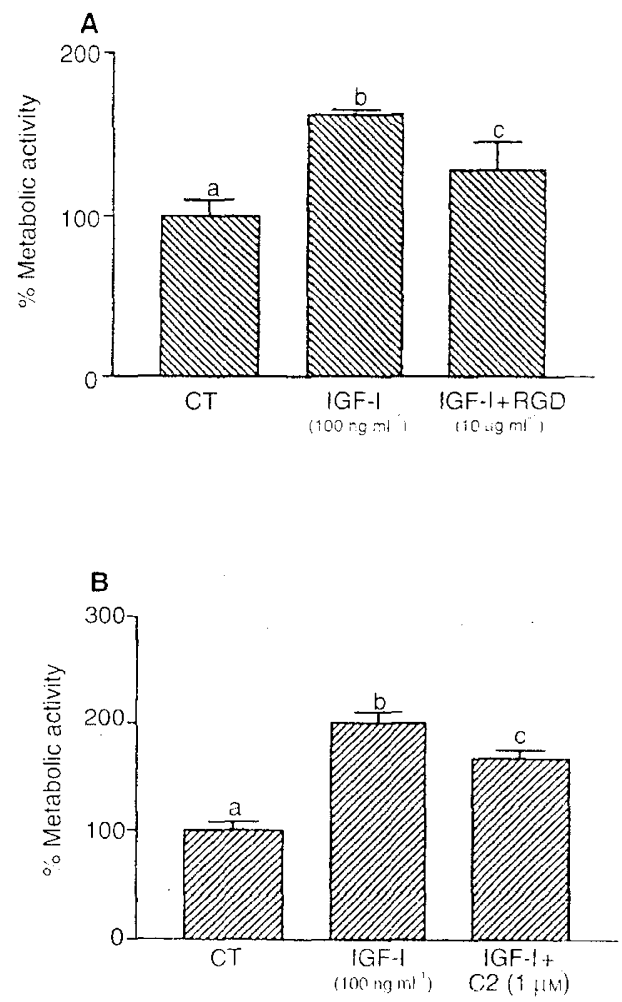

Figure 3 Effects of RGD and C2 in the T47D and MCF-7 cell lines, respectively, on the mitogenic effects of IGF-I. Results represent cells treated with IGF-I alone (100 ng $\mathrm{ml}$ ') and: (A) IGF-I in combination with RGD $\left(10 . \mathrm{g} \mathrm{ml}^{-1}\right)$ in the T47Ds in which $\mathrm{a}<\mathrm{b}(P<0.01), \mathrm{b}>\mathrm{c}(P<0.05)$, and a:c was not significant: (B) IGF-l in combination with $\mathrm{C} 2(1 \mu \mathrm{M})$ in the MCF-7 cells in which $\mathrm{a}<\mathrm{b}(P<0.01)$, $\mathrm{a}<\mathrm{c}(P<0.05)$, and $\mathrm{b}>\mathrm{c}(P<0.05)$. MTT activity was assayed as described in Materials and Methods. Results represent I. s.e.m. of five wells from one experiment, which is representative of experiments which have been repeated at least three times

programmed cell death. Many malignant fumours, including those in the beast. secrete IGF-I and IGl- 11 and orerexpess the lype I IGF receptor (Matcatily. 1992), which sugesests that the IGFs may be hey platers in promoting lumour growth in the breast.

Our results have shown that GGF-I atets as a potent mitogen in both the T47D and MCF-7 cell lines. The increase in total cell number in these cells was accompanied by a corresponding rise in the percentise of cells in the S-phatse of the crele. ats anticipated.

Nonapoptotic doses of RGD and C2 in the T+7D and MCF-7 cell lines. respectively, had no effect on total cell number compared with controls. The combination of these treatments with IGF-1 in the respective cell hines reduced the IGF-I increase in overall cells number. However. cell cyck analysis revealed that the number of cells in the $S$-phase of the cycle was unalfected by the addition of RGD of C 2 compared with IGF-1 alone.

Interestingly, we observed that $C 2$ was able 10 inhibit the mitogenic etfect of IGF-I in both the cell lines, but that RGD inhibited IGF-l actions in the T47D but not in the MCF-7 cells. Previous data have demonstrated that ligated integrins transmit specific signals: for example. ectopic expression of $\alpha .5 \beta 1$ integrin. but not ox $\beta$. suppressed apoptosis of fibronectin-bound Chinese hamster ovar! (CHO) cells (Zhang et al. 1995). Our data suggest. therefore. that the T47D and $M \mathrm{CF}-7$ cell lines have distinct complements of integrin receptors and so can respond differently to the sume RGD treatment. 

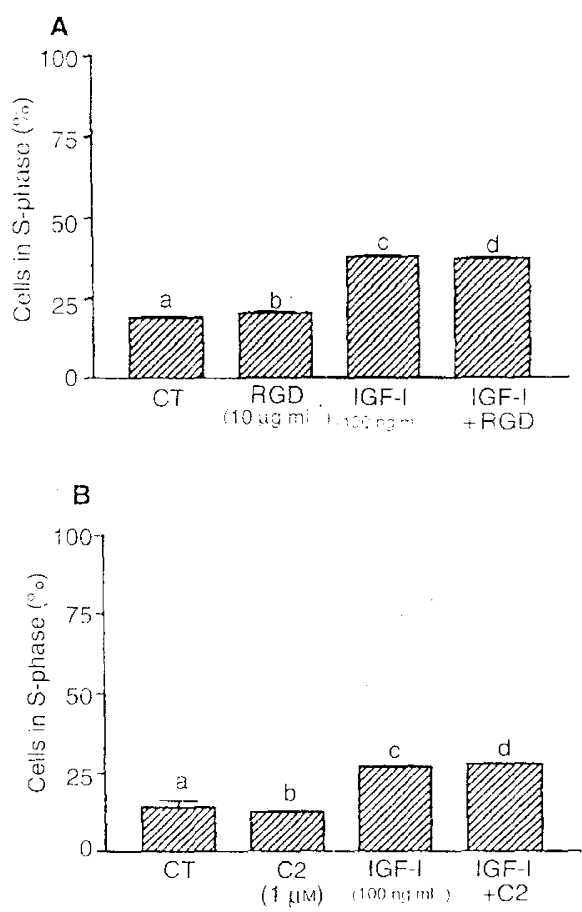

Figure 4 Flow cytometric analysis of the $\$$-phase of the cell cycle of T47D and $M C F-7$ cells treated with $R G D$ and $C 2$ respectively (A) T47D human breast cancer cells after treatment with RGD (10 / $\mathrm{g} \mathrm{ml} \mathrm{I),} \mathrm{IGF-l} \mathrm{(100} \mathrm{ng} \mathrm{ml})$ and RGD and IGF-I for $48 \mathrm{~h}$. Represents the percentage of cells in the $S$-phase of the cycle $(a<c+d, P<0.001: b<c+d, P<0.001: a<b$. $P<0.05 ; \mathrm{c}>d, P<0.05)$. (B) MCF-7 cells after treatment with $\mathrm{C} 2(1 \mu \mathrm{M})$, IGF-I (100 ng $\mathrm{ml}$ ') or $\mathrm{C} 2$ and IGF-I for $48 \mathrm{~h}$. Represents the percentage of colls in the S-phase of the cycle $(a<c+d . P<0.01: b<c+d, P<0.01$; $a: b$ and cod, $P>0.05$ ). Resulis are the means i s.e.rn. of experiments performed at least three times

Growth factors are reguired for cells to enter the ectl cycke, hut. once past (il phase completion of the cell cycte no longer requires

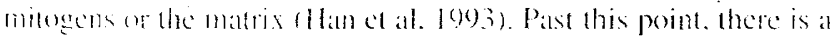
switch w intrinsic cell eycle mathinery made up of many different comproments that ensure an ordered progeression of cell division (Cirma and Reddy. 1945). One such member is the family of cyclins. which play an important roke in these events and underge priodic synthesis and degradition throughout the cycle. We. therefore. looked al exelin production simply as a marker of eell cycle progession to corroborate our low cytometry. MTT and cell counting data. Cyclins D) I. 2 and 3 are expressed in Gl in response 10 grow th factors cyclin $\mathrm{E}$ is produced later in $\mathrm{G} I$ and peaks at the Gils transition. S-phase is marked by the expression of eyclin A and this is required for the intiation and progression of DNA replication. Finally, cyclin $\mathrm{Bl}$ is maximally up-regulated during the transition from $\mathrm{G} 2 / \mathrm{M}$.

We found. using Western immunobloting, that in the MCF-7 cells IGF-I alone or in combination with $\mathrm{C}$ ? produced equivalent dramatic increases in production of cyclin A compared with coiltrol cells. This corresponded to the changes seen previously in the number of cells in the S-phase. as determined by cell cycle andysis. Furthermore. on examining cyclin Bl production. we observed that IGF-I alone caused significant increases in its levels relative to controls. but on co-incubation with $C_{2}$ these concentrations were reduced. This observation supported the reduction in orerall cell number that was seen on co-incubation of the MCF-7 cells with IGF-I and C2 compared with IGF-I alone. This indicated

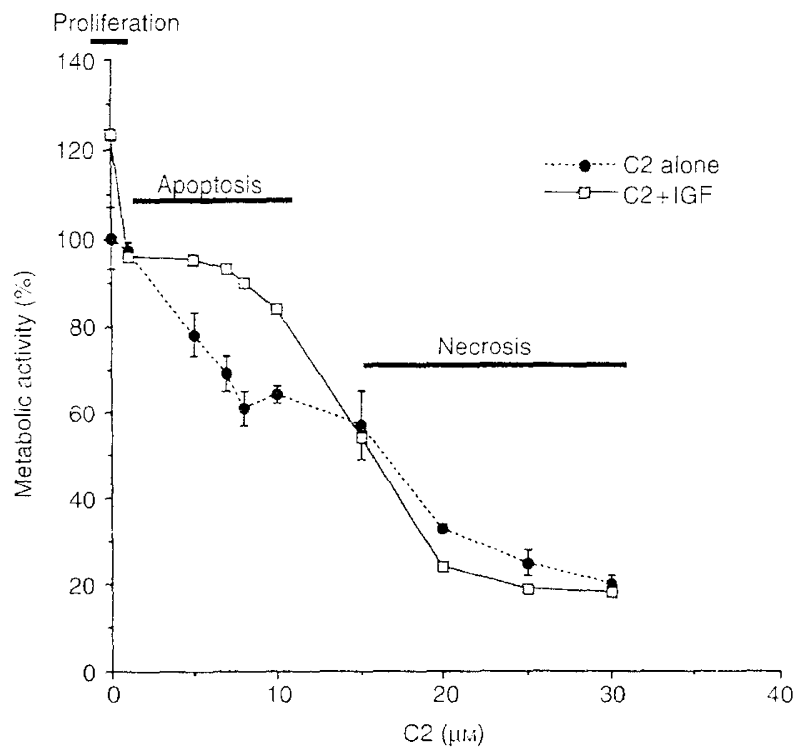

Figure 5 Represents a dose response to ceramide $(0-30 \mathrm{um})+\mid \mathrm{GF}-1$ (100 $\mathrm{ng} \mathrm{ml}$ ') for $24 \mathrm{~h}$. MTT activity was assayed as described in Materials and Methods. The results represent the means s.e.m. of five wells from one experiment, which is representative of experiments repeated at least three times.

A

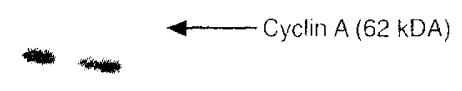

B

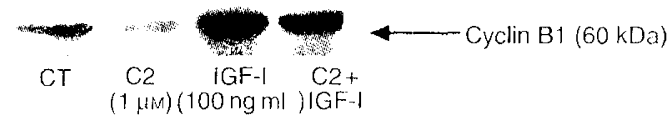

C

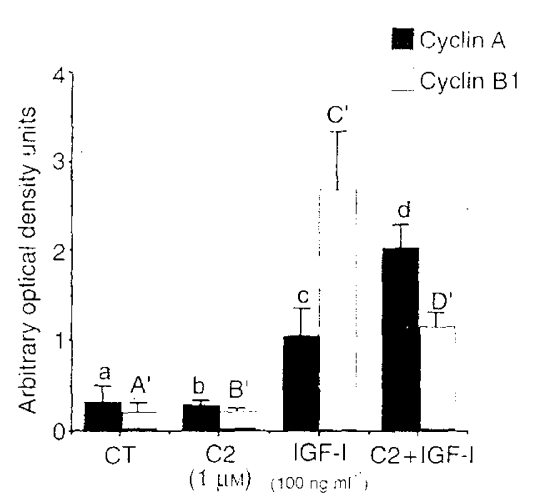

Figure 6 Measurement of cyclin $A$ and cyclin B1 by Western immunoblotting. Production of cyclins A $(60 \mathrm{kDa})$ and $\mathrm{B} 1(62 \mathrm{kDa})$ in MCF-7 cells treated for $48 \mathrm{~h}$ with $\mathrm{C} 2$ ( $1 \mathrm{\mu m}$ ). IGF-I alone $\left(100 \mathrm{ng} \mathrm{ml}^{-1}\right)$ or $\mathrm{C} 2 \mathrm{in}$ combination with IGF-1. $A$ and $B$ are representative immunoblots of cyclin $A$ and $B 1$ respectively. $C$ shows the means \pm s.e.m. optical density readings from immunoblots performed at least three times, in which for cyclin $B 1$ : $A^{\prime}: B^{\prime} . P>0.05 ; A^{\prime}<C^{\prime} . P<0.01 ; A^{\prime}<D^{\prime} . P<0.01 ; C^{\prime}>D^{\prime} . P<0.05$ and for cyclin A: a:b. $P>0.05: a<c . P<0.01: b<c, P<0.01: b<d . P<0.01: a<d$ $P<0.001$ 
that although cells were being pushed into the cell crcle this was not being completed by cell replication.

In summary. these data demonstrate that treatment of $\mathrm{MCF}-7$ and T47D cells with IGF-I alone or in combination with nonapoptotic doses of $\mathrm{C} 2$ or RGD. respectively. leads to comparable numbers of cells in the S-phase and equivalent concentrations of cycin A. whereas there is a reduction in both overall cell proliferation and production of cyclin B 1 . This analysis suggests that both $\mathrm{C} 2$ and RGD at nonapoptotic doses are able to block cells in the $S$-phase of the cycle. thereby modulating the normal cycle of events usually initiated by IGF-I. Therefore. these nonapoptotic doses of $\mathrm{C} 2$ and RGD have the ability to modulate the cell cycle events associated with the mitotic signal induced by IGF-I in these cell lines.

In conclusion. a balance between the rate of cell proliferation and cell death by apoptosis has to exist to ensure tissue homeostasis. A tumour could arise via a combination of inappropriate cell proliferation and reduced cell death by apoptosis. It has been demonstrated previously that cells require attachment to the matrix for normal growth but can be triggered into apoptosis by detachment from the substratum. Malignant cells have therefore. accuired the ability to undergo anchorage-independent growth. and are no longer susceptible to detachment as the normal trigger for programmed eell death. It has also been demonstrated previously that activation of ceramide signalling pathways via cytokines, radiotherapy and chemotherapy will induce programmed cell death. We have now shown that induction of ceramide and integrin signalling pathways at nonapoptotic doses can also have important consequences in tumour biology. Our datal suggest that the response to growth factor stimulation of cells may be modulated by fow-dose activation of ceramide and integrin signalling palhways

\section{ACKNOWLEDGEMENTS}

We wish to thank the Medical Research Council and Zenecal Plarmakeuticals for financial support.

\section{REFERENCES}

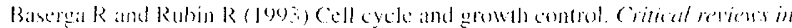

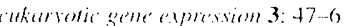

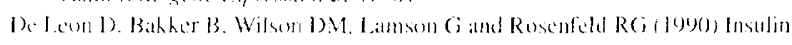

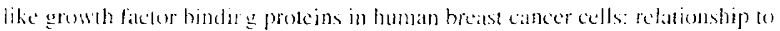

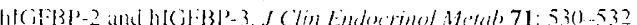

Freedman VH and Shin S1974, Cellular tumerigenicity in nude mice: correlation with cell grow th in semisolid mediun. Cell 3: 35:-359

Frisch S.Y and Francis H 1994 , Disruption of epithelial cell-matrix interaction induces apoptosis. J Cell Biol 124: 619-626

Giancotti FG and Ruoslahti E 1990 , Elevated levels of $\alpha . \beta$. fibronectin receptor suppress the transformed phenotype of $\mathrm{CHO}$ cells. Cell 60 : 849-859

Gill ZP. Perks CM. Newcomb PV and Holly JMP (1997a) Insulin-like growth factor binding protein-3 (IGFBP-3) predisposes breast cancer cells to programmed cell death in a non-IGF-dependent manner. I Binl Chem 272 $25602-25607$

Gill ZP. Perks C.I. Newcomb PV and Holly JMP ( 1997b) Grow th factor modulation of cell survival in response to a physiological signal for apoptosis in .MCF-7 and fibroblast (1BR3G) cell lines, J Enderinol 152: abstract P10-

Graña X and Reddy EP (1995) Cell cycle control in mammalian cells: role of cyclins. cyclin dependent kinases (CDKs). growth suppressor genes and cyclin dependent kinase inhibitors (CKI 5 ). Oncogene 11: 211-219

Han EK. Guadagno TW. Dalton SL, and Aswoian RK (1993) A cell cycle and mutational anilysis of anchorage-independent growth: cell adhesion and TGFBI control/Gl/S transit specifically. J C ell Biol 122: $461-471$

Hay man EG. Piersehbacher .MD and Ruoslahti E (1985) Detachment of cells from culture substrate by soluble fibronectin peptides. I Cell Biel 100: 1948-1954

Ingher DE (1990)) Fibronectin controls capillary endotheliat cell growth based on it

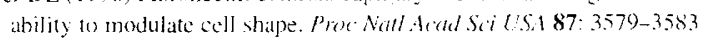

Knadon KA. Rao PF. Damsky $\mathrm{CH}$ and Buck CA 11981 , Membrane glycoproteins

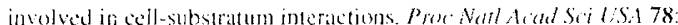
$6071-6075$

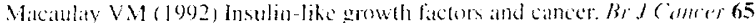
$3: 11+300$

Obeid I.M. Linardic CM. Karoliak LA and Hammun YA (1993) Programmed col death induced hy ceranide. Serionce 259: 1760 - 177

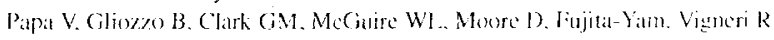
Peyrat JP and Bommetere $J(19) 3)$ Type I K(if recepter in human breas

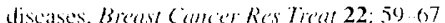

Perkis (M. Norman MR, Newcemb PV and Holly JMP (1997) The efled al R(iD) containing peptides on the phosphorylation of focal athesion kinase (IAKK) in

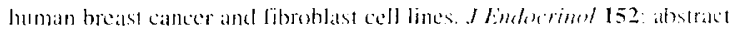
P105

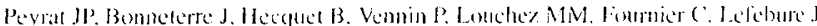

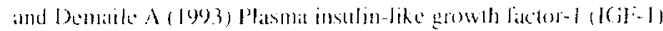

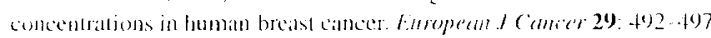

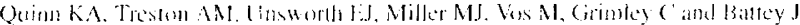
(1096) Insulin-like growth factor expression in human cancer cell lines. J Biol ('/lim $271: 11+777-11+43$

Rumstabtil: and Pierschbacher MI) (1987) New perspectives in call atherion

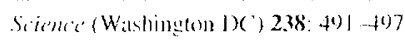

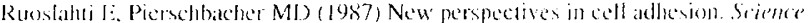
(Whash 1 () $238: 491 . .497$

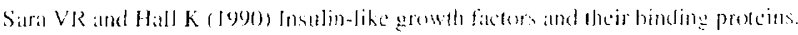

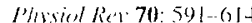

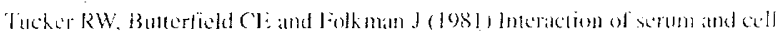
spreading affects growh of neoplastic and nomocoplastic cells. J Supramol Sinut 15: 20 40

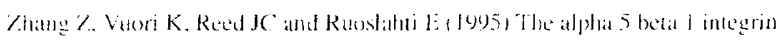
stpperts survival of ecells on fibronectin and up-regulates Bcl-2 expession.

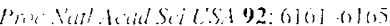

